\author{
ANNALS OF "DUNAREA DE JOS” UNIVERSITY OF GALATI \\ MATHEMATICS, PHYSICS, THEORETICAL MECHANICS \\ FASCICLE II, YEAR X (XLI) 2018, No. 2
}

Article DOI: https://doi.org/10.35219/ann-ugal-math-phys-mec.2018.2.12

\title{
ASSESSMENT OF CHEMICAL PARAMETERS IN THE LOWER DANUBE
}

\author{
Ionela Cotlogut ${ }^{1 *}$, Maria Catalina Topa ${ }^{1}$, Mihaela Timofti ${ }^{1}$, Gabriel Murariu ${ }^{1}$, \\ Maxim Arseni ${ }^{1}$, Catalina Iticescu ${ }^{1}$, Lucian P. Georgescu ${ }^{1}$ \\ 1* Faculty of Sciences and Environment, "Dunărea de Jos" University of Galati, 111 Domneasca Street, 800201, \\ Galati, Romania, e-mail: Ionela.Cotlogut@ugal.ro
}

\begin{abstract}
This paper aims at monitoring the water quality and the pollution degree on a relevant sector from the Lower Danube using the levels of nutrients, minerals, organic matters and the oxygen conditions as the specific indicators. For this study, water samples were taken from 5 different sampling stations: Priza Dunarii, the confluence of the Danube with the Siret and the Prut, Dunare-Liberatatea, and Cotul Pisicii. In order to determine the pollution degree of the Danube water in the adjacent area of Galati city, nine chemical parameters were analysed: total nitrogen, nitrates, nitrates, ammonia, total phosphorus, chlorides, sulphate ions, total organic carbon (TOC) and chemical oxygen demand (COD). The results obtained were used to assess and classify the quality of the Lower Danube water into quality classes according to the Water Framework Directive transposed in Order 161/2006.
\end{abstract}

Keywords: monitoring, Danube, chemical parameters, water quality

\section{INTRODUCTION}

The population growth and the industrialization and agricultural activities have led to high demand for fresh water and to the deterioration of the available water resources due to various contaminants [1,2]. Therefore, monitoring and assesing the water quality is an important activity based on analyzing, interpreting and communicating the physical, chemical, biological and microbiological properties of water in the framework of human activities and of environment conservation [3].

The aim of this study is to monitor the spatial and temporal variation of certain chemical parameters concentrations for assessing the water quality on a relevant sector from the Lower Danube according to the Water Framework Directive. Furthermore, the chlorophyll $a$ was determined in order to find the relationship between chl-a and the nutrients concentrations.

Monitoring the Danube water quality in the adjacent area of Galati city is important because the Danube is the main source of drinking water for the population of Galati.

The Lower Danube has as main tributaries the Prut and Siret Rivers and the water input of these rivers influences the Danube water quality. The agricultural and industrial activities carried out along the two rivers lead to agricultural runoff and industrial wastewaters which contain high concentrations of nutrients like nitrogen and phosphorous. In addition, the area of Galati city is highly industrialized. The increase of nutrient concentrations due to domestic wastewater, industrial wastewater and agricultural run-off is considered to be one of the major factors which cause the water eutrophication. This is a phenomenon which is a frequently mentioned cause of surface waters degradation $[4,5]$. Therefore, a permanent monitoring of the nutrient concentrations in this sector of the Danube River is required. The following indicators were analyzed: total nitrogen, nitrates, 
nitrates, ammonia, total phosphorus, chlorides, sulphate ions, total organic carbon (TOC) and chemical oxygen demand (COD). The admissible limits of these parameters for the five quality classes are presented in Table 1 below.

Table 1. The admissible limits of the analyzed chemical parameters for the 5 quality classes

[6]

\begin{tabular}{|c|c|c|c|c|c|}
\hline \multirow{2}{*}{ Parameters } & \multicolumn{5}{|c|}{ Quality classes } \\
\hline & $\mathbf{I}$ & II & III & IV & $\mathbf{V}$ \\
\hline TOC(mg C/L) & - & - & - & - & - \\
\hline $\mathrm{COD}\left(\mathrm{mg} \mathrm{O}_{2} / \mathrm{L}\right)$ & 10 & 25 & 50 & 125 & $>125$ \\
\hline $\mathrm{N}$ - total $(\mathrm{mg} / \mathrm{L})$ & 1.5 & 7 & 12 & 16 & $>16$ \\
\hline $\mathrm{N}-\mathrm{NO}_{3}^{-}(\mathrm{mg} / \mathrm{L})$ & 1 & 3 & 5.6 & 11.2 & $>11.2$ \\
\hline $\mathrm{N}-\mathrm{NO}_{2}^{-}(\mathrm{mg} / \mathrm{L})$ & 0.01 & 0.03 & 0.06 & 0.3 & $>0.3$ \\
\hline $\mathrm{N}-\mathrm{NH}^{+}{ }_{4}(\mathrm{mg} / \mathrm{L})$ & 0.4 & 0.8 & 1.2 & 3.2 & $>3.2$ \\
\hline$P$ - total $(\mathrm{mg} / \mathrm{L})$ & 0.15 & 0.4 & 0.75 & 1.2 & $>1.2$ \\
\hline $\mathrm{Cl}^{-}(\mathrm{mg} / \mathrm{L})$ & 25 & 50 & 250 & 300 & $>300$ \\
\hline $\mathrm{SO}^{2+}{ }_{4}$ & 60 & 120 & 250 & 300 & $>300$ \\
\hline
\end{tabular}

\section{EXPERIMENTAL}

Water samples were collected in the summer season over 3 months (June, July, August) from 5 different sampling stations: Priza Dunării (PD), the confluence of the Danube River with Siret River (DS), Danube - Libertatea (DL), Cotul Pisicii (CP) and the confluence of the Danube with Prut River (DP) (see Figure 1). The samples were collected according to the standards in force and analysed within the European Centre of Excellence for the Environment, "Dunarea de Jos" University of Galati $[7,8]$. For the water analysis, a filtration process was initially carried out, followed by spectrophotometric analysis using a Spectroquant NOVA 60 and Merck kit according to the standards in force. 9 chemical parameters were analysed: oxygen demand (COD), total organic carbon (TOC), total nitrogen, nitrate, nitrites (nitrite ions react with iron (II) ethylenediammonium sulfate to form a yellow to green-brown iron), ammonia, total phosphorus, chlorides, sulfate ions [9-17]. Chlorophyll a was determined according to the standards in force [18]. Correlations between chlorophyll a and nutrients concentration were determined by analyzing the Pearson correlation coefficients.

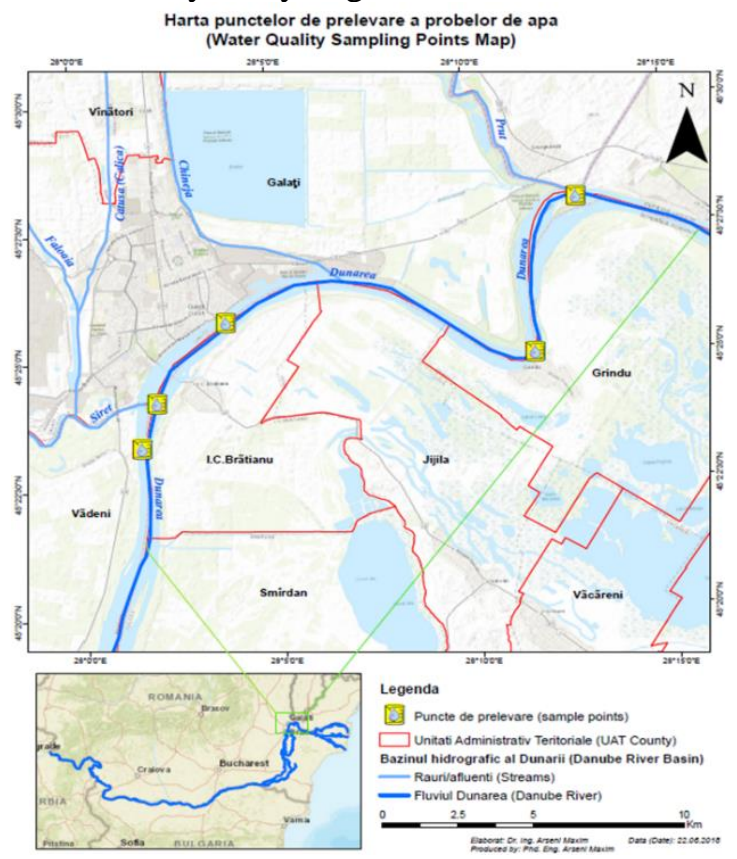

Fig. 1. Sampling stations map 
The results were evaluated using multivariate statistical techniques of PCA in order to investigate the variations of water quality parameters measured in 5 sampling station during summer season. PCA was performed on the standardized data sets containing 18 variables.

\section{RESULTS AND DISCUSSION}

Monitoring the COD and TOC content is important in assessing the degree of water pollution with organic pollutants, these indicators providing information on the presence and rate at which organic pollutants affect the water body $[19,20]$. In the present study chemical oxygen demand ranged between $15.6-26.8 \mathrm{mg} \mathrm{O}_{2} / \mathrm{L}$ (figure $2 \mathrm{a}$ ). These values are within the admissible limits presented in STAS 4706/88[21]. Total organic carbon content ranged from 19.5 to $29.2 \mathrm{mg} \mathrm{C/L}$ (figure $2 \mathrm{~b}$ ). According to the results, the Lower Danube has low content of organic pollutants in the adjacent area of Galati city.

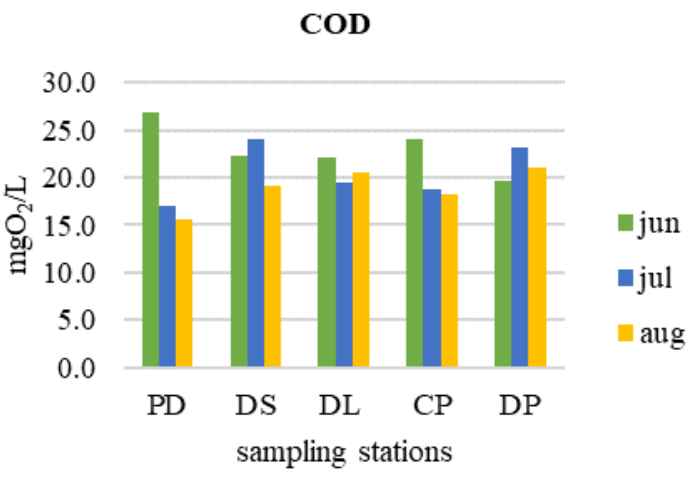

(a)

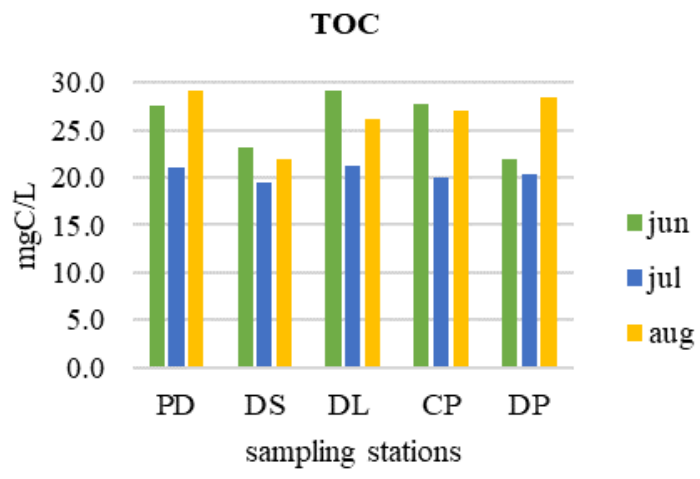

(b)

Fig. 2. Variation of COD (a) and TOC $(b)$ in the 5 sampling stations

Analysing the results of the nutrient regime monitoring the highest concentrations of nitrates were obtainded in July at the DS $(3.9 \mathrm{mg} / \mathrm{L})$ and DL $(2.6 \mathrm{mg} / \mathrm{L})$ sampling stations, but also in August at the PD sampling station $(2.8 \mathrm{mg} / \mathrm{L})$ (see Figure $3 \mathrm{~b}$ ). In the case of nitrites, the maximum values were measured in July at the DS $(3.9 \mathrm{mg} / \mathrm{L})$ and the DL $(2.6 \mathrm{mg} / \mathrm{L})$ sampling stations (see Figure $3 \mathrm{c}$ ). These high values registered are caused by agricultural and industrial activities carried out in those areas. The lowest concentration of nitrates was recorded in June at the CP $(1.3 \mathrm{mg} / \mathrm{L})$ and for nitrites in June at the confluence of the Danube with Siret River $(1.3 \mathrm{mg} / \mathrm{L})$. In August the most concentrations of nitrites were below the detection limit of the kit $(1 \mathrm{mg} / \mathrm{L})$, except for the DP station $(2.8 \mathrm{mg} / \mathrm{L})$.

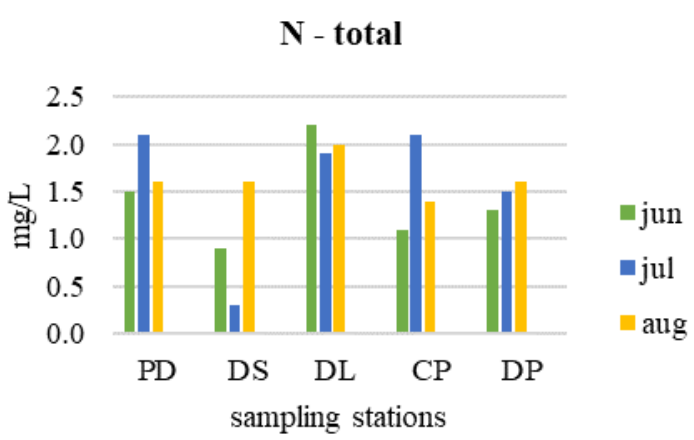

(a)

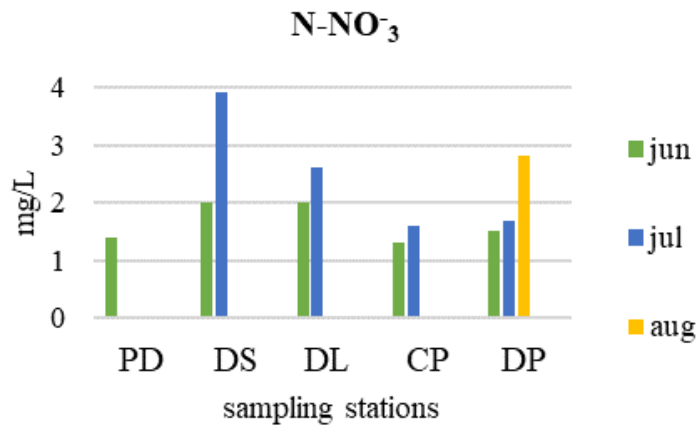

(b) 


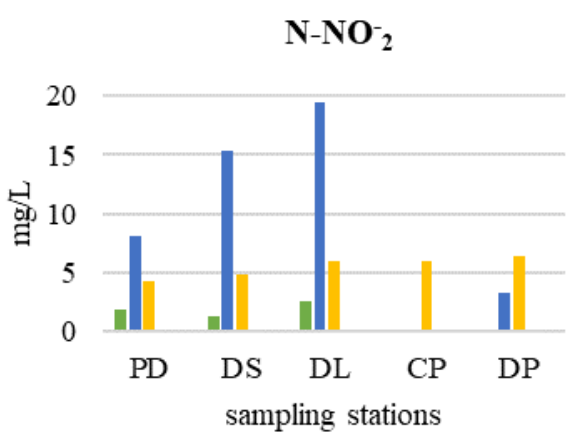

(c)

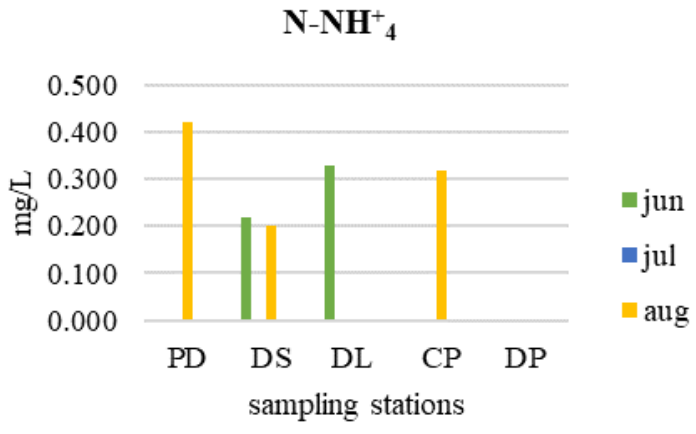

(d)

Fig. 3. Variation of $\mathrm{N}-$ total (a), $\mathrm{N}_{-} \mathrm{NO}_{3}^{-}{ }_{3}(b), \mathrm{N}_{-} \mathrm{NO}_{2}^{-}(c)$ and $\mathrm{N}_{-} \mathrm{NH}_{4}^{+}(d)$ in the 5 sampling stations

In the case of total nitrogen, the recorded values ranged from $0.3-2.2 \mathrm{mg} / \mathrm{L}$ (Figure $3 \mathrm{a}$ ). The maximum value was obtained at the DL sampling station in June, and the minimum value at the confluence of the Danube with Siret River (DS) in July. The N-total values do not exceed the admissible limits set by Ord.161/2006 for quality class II $(7 \mathrm{mg} / \mathrm{L})$. The most concentrations of $\mathrm{N}$ $\mathrm{NH}_{4}{ }^{+}$in the 5 sampling stations were very low, below the detection limit of the kit $(0.2 \mathrm{mg} / \mathrm{L})$, except for the DS $(0.22 \mathrm{mg} / \mathrm{L})$ and DL $(0.33 \mathrm{mg} / \mathrm{L})$ sampling stations in June and PD $(0.42 \mathrm{mg} / \mathrm{L})$, DS $(0.2$ $\mathrm{mg} / \mathrm{L})$ and $\mathrm{CP}(0.32 \mathrm{mg} / \mathrm{L})$ in August. The values are within the permissible limits set by Ord.161/2006 (Figure 3d).

The total phosphorus concentrations in the 5 monitoring sampling stations ranged between $0.02-5.95 \mathrm{mg} / \mathrm{L}$ (see Figure 3a). This parameter recorded high value at the DL sampling station in June $(5.95 \mathrm{mg} / \mathrm{L})$. The maximum value of P-total was 50 times above the admissible limit value of STAS 4706/ 88 [21]. This may indicate that an accidental pollution event took place in the area. The minimum concentration of phosphorus was recorded at the PD sampling station $(0.06 \mathrm{mg} / \mathrm{L})$ in June.

The chloride concentrations ranged between $26-47 \mathrm{mg} / \mathrm{L}$ (see Figure $4 \mathrm{~b}$ ) and the values were below the maximum permissible limits $200 \mathrm{mg} / \mathrm{L}$ [21]. In the case of sulfate ions, the most concentrations were below the detection limit of the kit $(50 \mathrm{mg} / \mathrm{L})$, except for DL sampling station in June $(51 \mathrm{mg} / \mathrm{L})$.

Chlorophyll a (chl-a) is the major photosynthetic pigment present in phytoplankton and it is used to measure algal biomass. Acorrding to certain specialists (Balali et al. 2013; Filstrup et Downing 201), the Chl a concentration is influenced by nutrients and high chlorophyll content in surface water can reflect an increase in nutrients concentration $[13,14]$. These results were also identifyable in our determinations, except for $\mathrm{N}$-total and sulfate.Table 2. Pearson correlation coefficients $(r)$ between chlorophyll $a$ concentration and nutrients concentration

\begin{tabular}{|l|c|}
\hline & r \\
\hline $\log \mathbf{C h l}$ a: $\mathbf{N}$ & -0.0643 \\
\hline $\log \mathbf{C h l}$ a: $\mathbf{N}-\mathbf{N O}^{-}$ & 0.4006 \\
\hline $\log \mathbf{C h l ~ a : ~} \mathbf{N}-\mathbf{N O}^{-}$ & 0.2795 \\
\hline $\log \mathbf{C h l ~ a : ~} \mathbf{N}-\mathbf{N H}^{+}{ }_{4}$ & -0.3095 \\
\hline $\log \mathbf{C h l ~ a : ~} \mathbf{P}$ & 0.32626 \\
\hline $\log \mathbf{C h l ~ a : ~} \mathbf{C l}^{-}$ & -0.1098 \\
\hline
\end{tabular}

Results show a moderate correlation between logarithm chlorophyll a and nitrates. Weak correlations between logarithm chlorophyll a, nitrites, ammonia and total phosphorus were noticed, but there was no significant correlation between logarithm chlorophyll a and total nitrogen and chlorides (Table 2). 


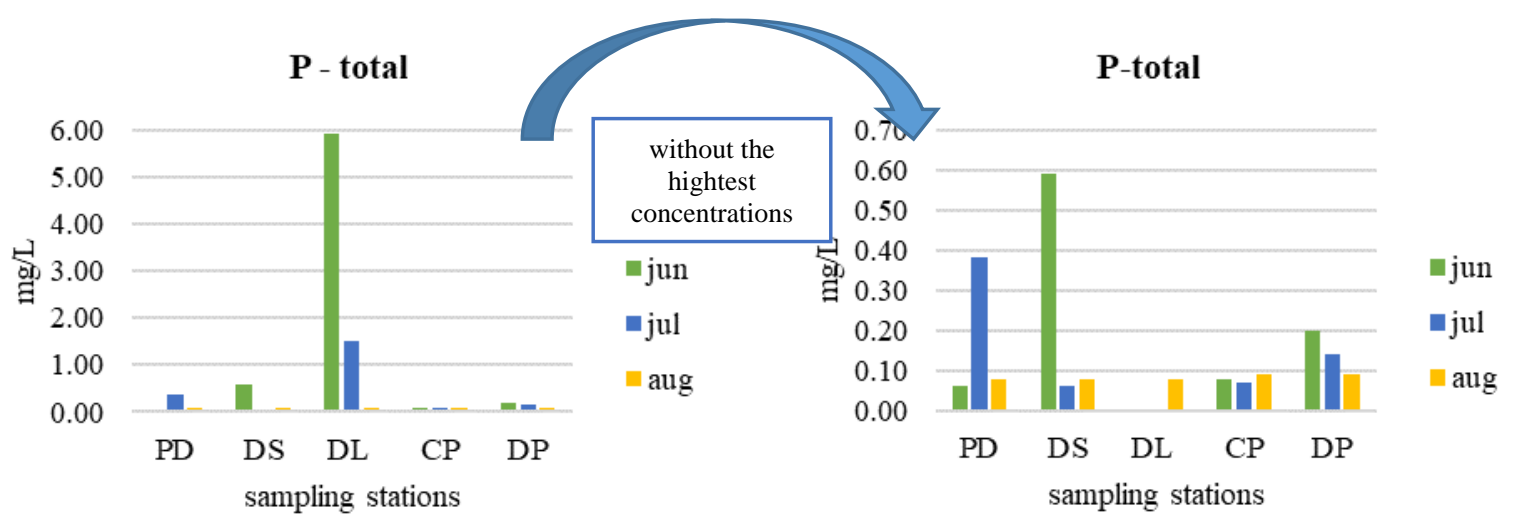

(a)

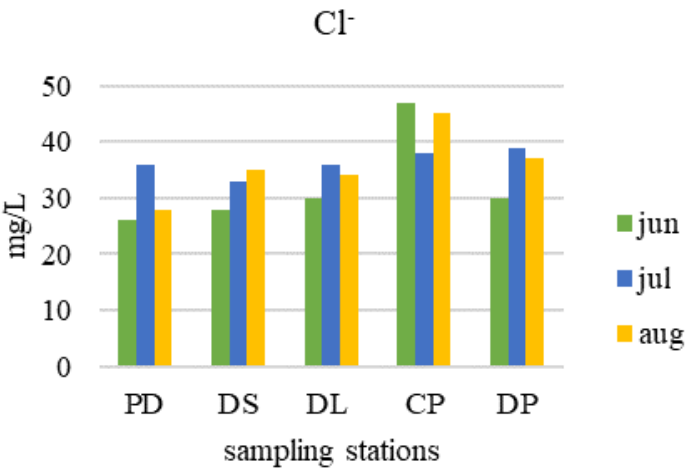

(b)

Fig. 4. Variation of $\mathrm{P}-$ total (a) and $\mathrm{Cl}^{-}(\mathrm{c})$ in the 5 sampling stations

The Principal Component Analysis was used to identify the variables which have greater significance to this study. In the PD sampling station, Factor 1 explained $67.46 \%$ of the total variance. It was highly correlated with $\mathrm{pH}$, T, TDS, DT, $\mathrm{N}-\mathrm{NO}_{2}$ and $\mathrm{N}-\mathrm{NO}_{3}$. Factor 2 explained 32.54 $\%$ of the total variance. It was influenced by $\mathrm{DO}, \mathrm{N}-\mathrm{NH}_{4}$ and turbidity (see figure $5 \mathrm{a}$ ).

In the DS sampling station, Factor 1 explained $60.60 \%$ of the variance. It was influenced by pH, SAL, TDS, DO, Dt, N-total and $\mathrm{N}^{-N_{4}}$. Factor 2 explained $39.40 \%$ of the variance and it was highy correlated with temperature, disolved oxygen, P-total, chlorides and turbidity (see figure $5 \mathrm{~b}$ ).

In the DL sampling station, Factor 1 explained $61.14 \%$ of the total variance. It was hight correlated with $\mathrm{pH}$, salinity, TDS, DO, temporary hardness, $\mathrm{N}$-total and $\mathrm{N}-\mathrm{NH}_{4}$. Factor 2 explained $38.86 \%$ of the variance and it was influenced by temperature, total hardness, $\mathrm{N}-\mathrm{NO}_{2}$ and $\mathrm{N}^{-\mathrm{NO}_{3}}$ (see figure 5c).

In the CP sampling station, Factor 1 explained $58.66 \%$ of the variance and is found to be strongly associated with $\mathrm{pH}$, conductivity, TDS, DO, total hardness, temporary hardness, $\mathrm{N}_{-} \mathrm{NO}_{2}, \mathrm{~N}-$ $\mathrm{NO}_{3}, \mathrm{~N}-\mathrm{NH}_{4}$ and $\mathrm{P}$ total. Factor 2 explained $43.54 \%$ of variance and it was influenced by temperature, MTS, salinity, COD and N-total (see figure 5d).

In the DP sampling station, Factor 1 explained $66.29 \%$ of total variance. It was influenced by $\mathrm{pH}$, conductivity, TDS, DO, turbidity, MTS, salinity, N-total, $\mathrm{N}-\mathrm{NO}_{2}, \mathrm{~N}-\mathrm{NO}_{3}$ and P-total. Factor 2 explained $33.71 \%$ of total variance. It was influenced by temperature, total hardness, COD and TOC (see figure $5 \mathrm{e}$ ). 


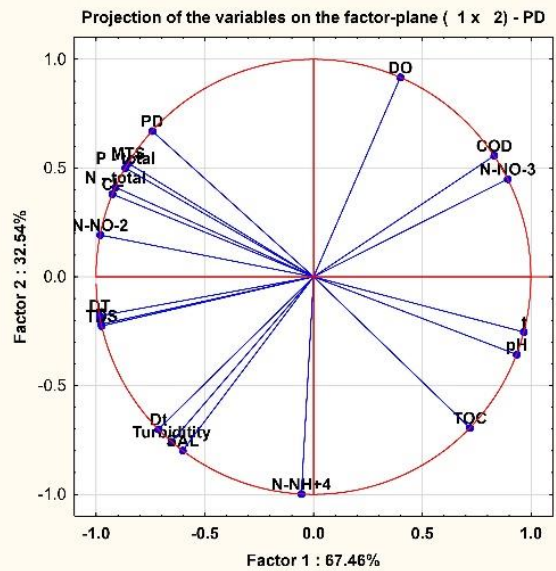

(a)

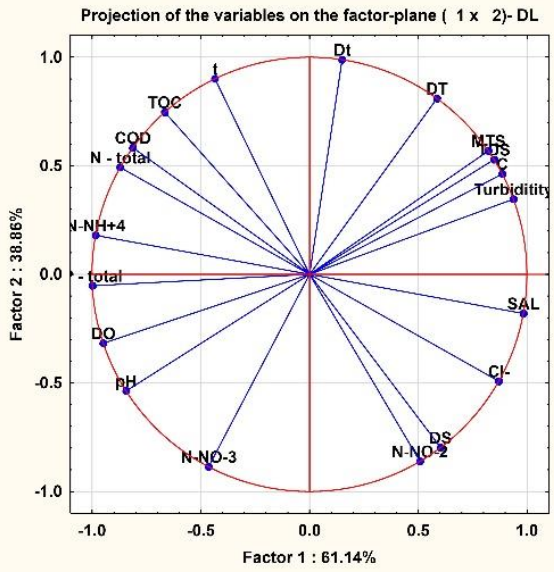

(c)

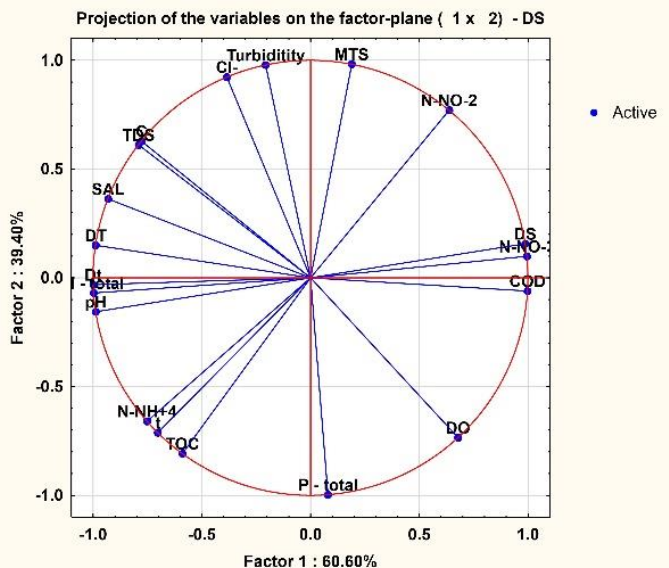

(b)

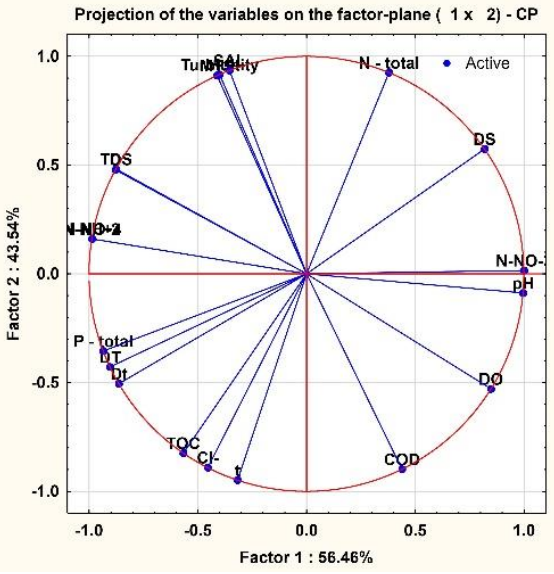

d)

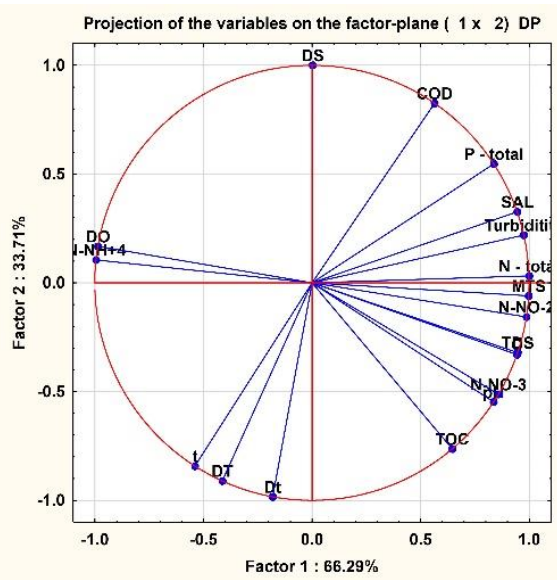

(e)

Fig. 5. Principal Component Analysis for parameters measured in the 5 sampling stations in summer season

\section{CONCLUSIONS}

The continuous analysis of the Danube water quality is an important stage in the monitoring process, both qualitatively and quantitatively. Following the analysis of the 9 chemical parameters, the results show an improvement in the Danube water quality. This could be explained by the municipal wastewater treatment plant but also by the Danube high capacity of self-purification. 
Water quality in the adjacent area of Galati may be classified in the quality class II according to the WFD transposed in Order 161/2006, with some exceedances of the minimum concentrations admitted in the sampling station situated at the confluence of the Danube with the tributaries the Siret and Prut. In addition, the investigations conclude that the concentrations of the most parameters analysed were within the admissible limits specified in STAS $4706 / 88$ on surface water quality except for the total phosphorus concentrations recorded in June and July in the sampling site Libertatea situated near a municipal wastewater discharger.

Significant correlations between chlorophyll a and nitrates were found in this research, moderate correlation between chlorophyll a and ammonia and the results show that the lower the amount of ammonia, the higher the amount of chlorophyll a. Moreover, the values obtained for chlorophyll a are not influenced by the concentrations of total nitrogen and chlorides.

Acknowledgement: This work was supported by the project "Strategy and actions for preparing the national participation in the DANUBIUS-RI Project" acronym "DANS" financed by the Romanian Ministry of Research and Innovation.

\section{References}

1. Varol M., Sen B., Assessment of surface water quality using multivariate statistical techniques: a case study of Behrimaz Stream, Turkey, Environ Monit Assess. 159, 543-553, 2009.

2. Bayoumi Hamuda H. E. A. F., Patkó I., Ecological Monitoring of Danube water Quality in Budapest Region, Am. J. Environ. Sci. 8(3), 202-211, 2012.

3. Cîrţînă, D., Aspecte privind monitorizarea calităţii apelor de suprafaţă. Analele Universităţii "Constantin Brâncuşi”" din Târgu Jiu, Seria Inginerie Nr. 1/2009, 101-112, 2009

4. Bayoumi Hamuda H. E. A. F., Patkó I., Variations in Water Quality of Danube River at Budapest City, Óbuda University e-Bulletin 2(1), 13 - 30, 2011

5. Ilie M., Marinescu F., Ghita G., Anghel A. M., Deák G., Raischi M., Assessment of NutrientsChlorophyll-a Relationship in the Lower Danube River, Int'l Journal of Advances in Chemical Engg., \& Biological Sciences (IJACEBS) 4(1), 15-20, 2017.

6. ORDER no. 161 of 16 February 2006 regarding the classification of surface water quality in order to establish the ecological status of water bodies

7. ISO 5667-1:2006(en), Water quality - Sampling - Part 1: Guidance on the design of sampling programmes and sampling techniques

8. ISO 5667-3:2018, Water quality -- Sampling -- Part 3: Preservation and handling of water sample

9. Spectroquant ${ }^{\circledR}$ COD Cell Test - instruction for use.

10. Spectroquant ${ }^{\circledR}$ TOC Cell Test - instruction for use.

11. Spectroquant ${ }^{\circledR}$ Nitrogen (total) Cell Test - instruction for use.

12. Spectroquant ${ }^{\circledR}$ Ammonium Cell Test - instruction for use.

13. Spectroquant ${ }^{\circledR}$ Nitrate Cell Test - instruction for use.

14. Spectroquant ${ }^{\circledR}$ Nitrite Cell Test - instruction for use.

15. Spectroquant ${ }^{\circledR}$ - Phosphate Cell Test - instruction for use.

16. Spectroquant ${ }^{\circledR}$ Chloride Cell Test - instruction for use.

17. Spectroquant ${ }^{\circledR}$ Sulphate Cell Test - instruction for use.

18. SR ISO 10260:1996 Water quality. Measurement of biochemical parameters. Spectrometric determination of chlorophyll "a"

19. Iticescu C., Georgescu L. P., Topa C., Murariu, G., Monitoring the Danube Water Quality near the Galati City, Journal of Environmental Protection and Ecology, 15(1), 30-38, 2014.

20. Lee, J.; Shin, K.; Park, C.; Lee, S.; Jin, D. R.; Kim, Y.; Yu, S. Spatial and seasonal variations of organic carbon level in four major rivers in Korea. Environmental Engineering Research, 21(1), 84-90, 2016. 
21. STAS 4706/88 Surface Waters. Categories and technical conditions of quality

22. Balali S.,Hoseini S.A., Ghorbani R., Kordi H. Relationships between nutrients and chlorophyll-a concentration in the international Alma Gol Wetland, Iran. Int. J. Aquat. Biol. 4(3), 1-5, 2013

23. Filstrup C. T., Downing J. A., Relationship of chlorophyll to phosphorus and nitrogen in nutrient-rich lakes, Inland Waters 7(4), 385-400, 2017 